\title{
Characterization of a recombinant thermotolerant argonaute protein as an endonuclease by broad guide utilization
}

\author{
Yuesheng Chong, Qian Liu, Fei Huang, Dong Song and Yan Feng* (1)
}

\begin{abstract}
Background: Prokaryotic argonaute proteins (pAgos) play an important role in host defense in vivo. Most importantly, the thermophilic pAgos with endonuclease activity hold great potential for programmable genetic manipulation. Therefore, exploring argonaute proteins with unique enzyme properties is desired for understanding their diverse catalytic mechanisms and promoting their applications in biotechnology.

Results: The argonaute protein from archaeon Methanocaldococcus fervens (MfAgo) was cloned and overexpressed in Escherichia coli BL21 (DE3). The recombinant protein showed the expected molecular weight of $\sim 85.8 \mathrm{kDa}$ by SDSPAGE. The activity assays demonstrate that MfAgo has cleavage activities toward single-stranded DNA (ssDNA) targets specifically at the site complementary to the position between nucleotides 10 and 11 of the guide strand. Interestingly, MfAgo utilizes small 5'-phosphorylated ssDNA (5'-P ssDNA), 5'-hydroxylated ssDNA (5'-OH ssDNA), and 5'-phosphorylated ssRNA (5'-P ssRNA) as the guides for catalysis. The optimal temperatures are highly dependent on the type of guide and have a range of $80-90^{\circ} \mathrm{C}$. The addition of $0.5 \mathrm{mM} \mathrm{Mn}^{2+}, \mathrm{Mg}^{2+}$ or $\mathrm{Co}^{2+}$ to the reaction system significantly enhanced the enzyme activity. Meanwhile, MfAgo is quite active at $\mathrm{NaCl}$ concentrations less than $500 \mathrm{mM}$. Furthermore, structural modeling analyses suggested that its unique wide guide-dependent activity might be related to differing multiple interactions between guides and the MID domain of MfAgo.
\end{abstract}

Conclusions: MfAgo shows efficient endonuclease activity for ssDNA cleavage. In contrast to most known pAgos, which recognize only one type of guide, MfAgo uses diverse guides, including 5'-P ssDNA, 5'-OH ssDNA, and 5'-P ssRNA, to specifically cleave targets. Characterization of MfAgo expands the understanding of catalysis in the Ago family and provides clues for future genetic manipulation.

Keywords: Argonaute protein, Nucleic acid guide, Endonuclease, DNA cleavage, Homologous modeling

\section{Background}

Argonaute proteins (Agos) are widely present in all domains of life and bind small DNA or RNA guides to specifically recognize-and sometimes cleave-complementary nucleic acid targets (Swarts et al. 2014a). Eukaryotic argonaute proteins (eAgos) are the key components in RNA interference (RNAi) pathways that participate in the regulation of post-transcriptional gene expression

\footnotetext{
*Correspondence: yfeng2009@sjtu.edu.cn

State Key Laboratory of Microbial Metabolism, School of Life Sciences and Biotechnology, Shanghai Jiao Tong University, 800 Dongchuan Road,
} Shanghai 200240, China
(Bartel 2009; Ketting 2011; Meister 2013; Siomi et al. 2011). Recently, pAgos, including bacterial and archaeal Agos, were supposed to participate in host defense processes by interfering with exogenous nucleic acid infection (Olovnikov et al. 2013; Swarts et al. 2014a, 2015a, b). Genome analysis of prokaryotes reveals that pAgos are more diverse than eAgos since they are distributed in $30 \%$ of bacterial and $10 \%$ of archaeal sequenced genomes (Koonin 2017; Makarova et al. 2009; Swarts et al. 2014b). The functions of pAgos are relatively poorly understood and need to be further investigated.

Previous structural and biochemical studies of pAgos from thermophilic prokaryotes showed that they exhibit 
endonuclease activity directed by nucleic acid guides, which is similar to CRISPR-Cas9 activity. The characterized pAgos showed a preference for high temperature, generally ranging from 65 to $95{ }^{\circ} \mathrm{C}$, and a divalent cation requirement. As an endonuclease of Watson-Crick guidetarget pairing, the pAgos have unique guide preferences. To date, most pAgos perform specific cleavage via one type of guide from all four natural types of small nucleic acids: $5^{\prime}-\mathrm{P}$ ssDNA, 5'-OH ssDNA, 5'-OH ssRNA, and 5'-P ssRNA. For example, Agos from Pyrococcus furiosus (PfAgo) (Rivas et al. 2005; Song et al. 2004; Swarts et al. 2015a), Aquifex aeolicus (AaAgo) (Rashid et al. 2007; Yuan et al. 2005, 2006), Methanocaldococcus jannaschii (MjAgo) (Willkomm et al. 2017; Zander et al. 2014, 2017), and Thermus thermophilus (TtAgo) (Sheng et al. 2014; Swarts et al. 2014a, 2015b, 2017; Wang et al. 2008a, b, 2009) cleave complementary nucleic acid targets using 5'-P ssDNA guides. Meanwhile, Agos from Marinitoga piezophila (MpAgo) (Doxzen and Doudna 2017; Kaya et al. 2016) and Thermotoga profunda (TpAgo) (Kaya et al. 2016) use the 5'-OH ssRNA guide to cleave nucleic acid targets, whereas the Rhodobacter sphaeroides Ago (RsAgo) (Miyoshi et al. 2016; Olovnikov et al. 2013) utilizes a 5'-P ssRNA guide to recognize cognate nucleic acid targets (Table 1). Notably, the structural analysis indicates that the distinct guide preferences are strongly associated with the guide $5^{\prime}$-endbinding pocket of the MID domain, as reasoned by the available space and hydrophobic or charged environment (Kaya et al. 2016; Wang et al. 2008b).

Recently, the application of Agos has gradually attracted researchers' interest. Based on PfAgo-specific dsDNA cleavage via a pair of $5^{\prime}-\mathrm{P}$ ssDNA guides, the artificial restriction enzymes' (AREs) platform has been developed to enable to cleave target DNA sequences at virtually any arbitrary site (Enghiad and Zhao 2017). Further, mining and biochemical characterizations of pAgos are greatly demanded to understand their basic biological roles and to explore their application potentials for genome manipulation (Ryazansky et al. 2018).

Based on a phylogenetic tree analysis, we found a putative endonuclease pAgo from the hyperthermophilic archaeon Methanocaldococcus fervens (MfAgo). To better understand its catalytic function, MfAgo was cloned and overexpressed in E. coli BL21 (DE3) for biochemical characterization. Moreover, computational simulation analysis was carried out to reveal its nucleic acid guide preferences. Our study demonstrates that MfAgo is a unique endonuclease with DNA cleavage activity directed by a wide range of guides that provides a new enzyme resource for future gene manipulation.

\section{Methods}

Bacterial strain, plasmid, and medium

The host strain E. coli BL21(DE3) was purchased from Novagen (Madison, WI). The recombinant plasmid pET-28a(+)-MfAgo, containing the synthesized codonoptimized MfAgo gene, was constructed (Genscript, China). Luria-Bertani (LB) medium (tryptone $10 \mathrm{~g} / \mathrm{L}$, yeast extract $5 \mathrm{~g} / \mathrm{L}, \mathrm{NaCl} 10 \mathrm{~g} / \mathrm{L}$ ) was used for $M f A g o$ expression.

\section{Phylogenetic tree and sequence alignment}

A similarity search for the PfAgo amino acid sequence was performed by BLAST in the NCBI database, and

Table 1 Guide and target preferences of characterized pAgo proteins

\begin{tabular}{|c|c|c|c|c|c|c|c|c|}
\hline \multicolumn{2}{|l|}{ pAgo proteins } & \multicolumn{2}{|c|}{ Guide information } & \multicolumn{4}{|l|}{ Activity } & \multirow[t]{2}{*}{ References } \\
\hline Host & $\begin{array}{l}\text { Argonaute } \\
\text { name }\end{array}$ & Guide & $\begin{array}{l}5^{\prime} \text {-end } \\
\text { nucleotide } \\
\text { preference }\end{array}$ & $\begin{array}{l}\text { RNA-guided } \\
\text { RNA interference }\end{array}$ & $\begin{array}{l}\text { RNA-guided } \\
\text { DNA interference }\end{array}$ & $\begin{array}{l}\text { DNA- } \\
\text { guided RNA } \\
\text { interference }\end{array}$ & $\begin{array}{l}\text { DNA-guided DNA } \\
\text { interference }\end{array}$ & \\
\hline $\begin{array}{c}\text { Methanocal- } \\
\text { dococcus } \\
\text { jannaschii }\end{array}$ & MjAgo & DNA & $5^{\prime}-P$ & - & - & - & + & $\begin{array}{l}\text { Zander et al. } \\
\text { (2014) }\end{array}$ \\
\hline $\begin{array}{l}\text { Rhodobacter } \\
\text { sphaeroides }\end{array}$ & RsAgo & RNA & $5^{\prime}-P$ & - & + & - & - & $\begin{array}{l}\text { Olovnikov et al. } \\
\text { (2013) }\end{array}$ \\
\hline Aquifex aeolicus & AaAgo & DNA & $5^{\prime}-P$ & - & - & + & - & Yuan et al. (2005) \\
\hline $\begin{array}{l}\text { Marinitoga } \\
\text { piezophila }\end{array}$ & MpAgo & RNA & $5^{\prime}-\mathrm{OH}$ & + & + & - & - & Kaya et al. (2016) \\
\hline $\begin{array}{c}\text { Thermotoga } \\
\text { profunda }\end{array}$ & TpAgo & RNA & $5^{\prime}-\mathrm{OH}$ & - & + & - & - & Kaya et al. (2016) \\
\hline $\begin{array}{l}\text { Thermus ther- } \\
\text { mophilus }\end{array}$ & TtAgo & DNA & $5^{\prime}-P$ & - & - & + & + & $\begin{array}{l}\text { Wang et al. } \\
\text { (2008a) }\end{array}$ \\
\hline $\begin{array}{l}\text { Pyrococcus } \\
\text { furiosus }\end{array}$ & PfAgo & DNA & $5^{\prime}-P$ & - & - & - & + & $\begin{array}{l}\text { Swarts et al. } \\
\text { (2015a) }\end{array}$ \\
\hline
\end{tabular}


Ago sequences with high sequence identity were selected and analyzed by MEGA 7.0 software (Kumar et al. 2016) to construct a phylogenetic tree. The sequence alignments of the Ago family were carried out using ClustalW (Thompson et al. 1994). For clarity, only residues forming the active sites are displayed.

\section{Cloning and expression of MfAgo in E. coli BL21 (DE3)}

The expression vector pET-28a(+)-MfAgo was transformed into the E. coli BL21 (DE3) strain to express the recombinant MfAgo. Then, the positive clones were propagated overnight in a shaker incubator at $37{ }^{\circ} \mathrm{C}$ and $220 \mathrm{rpm}$ in $5-\mathrm{mL}$ LB medium containing $100 \mu \mathrm{g} / \mathrm{mL} \mathrm{kan}-$ amycin. After overnight incubation, the seed culture (1\%) was inoculated into $1-\mathrm{L} \mathrm{LB}$ medium containing $100 \mu \mathrm{g} /$ $\mathrm{mL}$ kanamycin at $37^{\circ} \mathrm{C}$ and incubated at $220 \mathrm{rpm}$ until an $\mathrm{OD}_{600}$ value of $0.6-0.8$ was reached. Cultures were coldshocked by incubation in an ice bath for $15 \mathrm{~min}$. Protein expression was then induced by the addition of isopropyl $\beta$-D-thiogalactopyranoside (IPTG) to a final concentration of $1 \mathrm{mM}$, followed by incubation for $16 \mathrm{~h}$ at $20{ }^{\circ} \mathrm{C}$ and $220 \mathrm{rpm}$ in a shaker incubator. Cells were harvested for centrifugation for $20 \mathrm{~min}$ at $6000 \mathrm{rpm}$, and the cell pellet was collected for later purification.

\section{Purification of recombinant $M$ fAgo}

The harvested cell pellets were resuspended in lysis buffer (20 mM Tris-HCl, $1 \mathrm{M} \mathrm{NaCl}, \mathrm{pH}$ 8.0) and then disrupted using a high-pressure homogenizer (Gefran, Italy) at $600-800$ bar for $3 \mathrm{~min}$. The lysates were incubated at $65^{\circ} \mathrm{C}$ for $15 \mathrm{~min}$ to eliminate most of the endogenous proteins of $E$. coli BL21 (DE3). Then, the solution was centrifuged for $30 \mathrm{~min}$ at $4{ }^{\circ} \mathrm{C}$ and $12,000 \mathrm{rpm}$, and then, the supernatants were loaded onto an $\mathrm{Ni}-$ NTA column. The N-terminal His-tagged MfAgo was eluted with elution buffer $(20 \mathrm{mM}$ Tris- $\mathrm{HCl}, 1 \mathrm{M} \mathrm{NaCl}$, $200 \mathrm{mM}$ imidazole, pH 8.0). Finally, size-exclusion chromatography (Superdex 200, GE) was further carried out with FPLC (Agilent, USA). The eluted recombinant protein was detected and analyzed by $15 \%$ SDS-PAGE.
The concentration of purified MfAgo was measured by the bicinchoninic acid (BCA) method (Yeasen, China), and the fractions containing the protein were frozen at $-80{ }^{\circ} \mathrm{C}$ in storage buffer $(20 \mathrm{mM}$ Tris- $\mathrm{HCl}, 1 \mathrm{M} \mathrm{NaCl}$, $15 \%(\mathrm{v} / \mathrm{v})$ glycerol, $\mathrm{pH}$ 8.0).

\section{Enzymatic characteristics of the recombinant MfAgo in vitro \\ Endonuclease activity assays}

The ssDNA or ssRNA guides and fluorescently labeled ssDNA or ssRNA targets were synthesized commercially (Genscript, China). For activity assays, $2.5 \mu \mathrm{M}$ purified $M$ fAgo, $2 \mu \mathrm{M}$ ssDNA or ssRNA guide, and $1 \mu \mathrm{M}$ fluorescently labeled ssDNA or ssRNA target were mixed in a reaction buffer $(15 \mathrm{mM}$ Tris- $\mathrm{HCl}, 250 \mathrm{mM} \mathrm{NaCl}, 0.5 \mathrm{mM}$ $\mathrm{MnCl}_{2}, \mathrm{pH} 8.0$ ) and then incubated for $35 \mathrm{~min}$ at $85^{\circ} \mathrm{C}$ in a thermocycler (Eppendorf, GER). After high-temperature incubation, the reactions were stopped via the addition of loading buffer (95\% formamide, $0.5 \mathrm{mmol} / \mathrm{L}$ EDTA, 0.025\% bromophenol blue, $0.025 \%$ xylene cyanol FF) at a 1:1 ratio $(\mathrm{v} / \mathrm{v})$. Then, the samples were resolved on $16 \%$ denaturing polyacrylamide gels. The gels were visualized on a Fuji FLA7000 scanner with fluorescence measurements with a $\lambda_{\mathrm{ex}}$ of $535 \mathrm{~nm}$ and a $\lambda_{\mathrm{em}}$ of $595 \mathrm{~nm}$. All the nucleic acids used in this study are listed in Table 2.

\section{MfAgo activity at the varied temperatures}

The effects of temperature on MfAgo activity mediated by different guides were determined at various temperatures from 55 to $99^{\circ} \mathrm{C}$. Generally, $2.5 \mu \mathrm{M}$ MfAgo, $2 \mu \mathrm{M}$ ssDNA or ssRNA guide, and $0.8 \mu \mathrm{M}$ ssDNA targets were mixed in the reaction buffer and then incubated for $30 \mathrm{~min}$ at 54.8 , $58.3,60.7,66.0,71.0,75.0,80.0,85.0,90.0,95.1,96.9$, and $98.7{ }^{\circ} \mathrm{C}$, respectively. The samples were resolved on $16 \%$ denaturing polyacrylamide gels. Gels were stained using GelRed (Biotium, USA). The nucleic acids were visualized using a G:BOX Chemi imager (Syngene, USA) and quantitatively analyzed by Quantity One (Bio-Rad, USA).

For the stability of varied guides at high temperatures, $2 \mu \mathrm{M}$ ssDNA or ssRNA guide was first pre-incubated in the reaction buffer at $95{ }^{\circ} \mathrm{C}$ for different times: $0,5,10$,

Table 2 Nucleic acids used in the study

\begin{tabular}{|c|c|c|}
\hline Name & Sequence $\left(5^{\prime}-3^{\prime}\right)$ & 1st Fig. \\
\hline ssDNA target (FAM) & FAM-GTCTGTGACTCCATAGAAAATCTTTCTCCTGCTCAGTGATTTCAG & Figure $3 a$ \\
\hline ssRNA target (FAM) & FAM-GUCUGUGACUCCAUAGAAAAUCUUUCUCCUGCUCAGUGAUUUCAG & Figure $3 a$ \\
\hline 5'-P ssDNA guide & P-TGAAATCACTGAGCAG & Figure $3 a$ \\
\hline 5'-OH ssDNA guide & HO-TGAAATCACTGAGCAG & Figure $3 a$ \\
\hline 5'-P ssRNA guide & P-UGAAAUCACUGAGCAG & Figure $3 a$ \\
\hline 5'-OH ssRNA guide & HO-UGAAAUCACUGAGCAG & Figure $3 a$ \\
\hline ssDNA target & GTCTGTGACTCCATAGAAAATCTTTCTCCTGCTCAGTGATTTCAGAGAGAGGATCTCGTG & Figure 4 \\
\hline
\end{tabular}


15 , and $30 \mathrm{~min}$, respectively. Subsequently, with the addition of $2.5 \mu \mathrm{M} M$ fAgo and $0.8 \mu \mathrm{M}$ ssDNA targets, the cleavage assay was performed at $80{ }^{\circ} \mathrm{C}$ for $30 \mathrm{~min}$. The samples were stained and visualized as above.

\section{Effect of divalent cations on MfAgo activity}

The effects of divalent cation on MfAgo cleavage activity were determined using different divalent cations. For the assays, $2.5 \mu \mathrm{M} M f A g o, 2 \mu \mathrm{M}$ ssDNA or ssRNA guide, and $0.8 \mu \mathrm{M}$ ssDNA targets were mixed in a reaction buffer (15 mM Tris-HCl, $250 \mathrm{mM} \mathrm{NaCl}, \mathrm{pH}$ 8.0) to which different divalent cations $\left(\mathrm{FeCl}_{2}, \mathrm{CoCl}_{2}, \mathrm{CuCl}_{2}, \mathrm{MgCl}_{2}\right.$, $\mathrm{MnCl}_{2}, \mathrm{ZnCl}_{2}$, and $\mathrm{CaCl}_{2}$ ) were added to a final concentration of $0.5 \mathrm{mM}$, and the samples were then incubated for $30 \mathrm{~min}$ at $85{ }^{\circ} \mathrm{C}$. The cleavage activity without the addition of a divalent cation was used as a control.

The optimal $\mathrm{Mn}^{2+}$ concentration for MfAgo cleavage activity was also determined using buffer with different final concentrations of $\mathrm{Mn}^{2+}: 5,10,25,50,100,250,500$, 1000,2000 , and $2500 \mu \mathrm{M}$, respectively. All the samples were stained and analyzed as above.

\section{Effect of $\mathrm{NaCl}$ concentration on MfAgo activity}

The influence of $\mathrm{NaCl}$ concentration on the catalytic activity of recombinant $M$ fAgo was investigated using buffer systems with various $\mathrm{NaCl}$ concentrations (50, $100,250,500,750,1000,1500$, and $2000 \mathrm{mM}$, respectively). The samples were stained and analyzed as above.

\section{Kinetic performance of MfAgo mediated by different guides}

For a cleavage kinetic analysis, the concentrations of $M f$ Ago, ssDNA targets, and different guides were the same as above. The assays were performed at $250 \mathrm{mM}$ $\mathrm{NaCl}$ and $2 \mathrm{mM} \mathrm{Mn}{ }^{2+}$ at $85{ }^{\circ} \mathrm{C}$ for different times: 0,1 , $3,5,10,20,30,45,60,80,100,120,150$, and $180 \mathrm{~min}$, respectively. The samples were resolved on $16 \%$ denaturing polyacrylamide gels and quantitatively analyzed by Quantity One (Bio-Rad, USA) to measure the cleavage efficiency of $M f A g o$ mediated by different guides.

\section{Homology modeling and structural analysis}

Homology modeling for MfAgo was determined using the SWISS-MODEL online tool (https://www.swiss model.expasy.org/) (Waterhouse et al. 2018) by using the binary structure of MjAgo with the $5^{\prime}$-P ssDNA guide (PDB ID: 5G5T, identity 68\%) (Willkomm et al. 2017) as the template; then, the $5^{\prime}-\mathrm{P}$ ssDNA, $5^{\prime}-\mathrm{OH}$ ssDNA, and $5^{\prime}$-P ssRNA guides were docked into the MfAgo model structure using the Schrodinger software (Repasky et al. 2007). An electrostatic heat map and the specific region where MfAgo binds the guide were analyzed by PyMol.

\section{Results and discussion}

\section{Phylogenetic tree and sequence analysis of $M f$ Ago}

To discover new functional biological resources in pAgos, we constructed a phylogenetic tree by aligning the PfAgo amino acid sequences in the NCBI database (Fig. 1a). MfAgo was chosen as the candidate because it is most closely related to hyperthermophilic MjAgo, with 68\% shared identity. Then, the sequence analysis of MfAgo was performed in detail. The MfAgo gene (GenBank Accession No. NC013156) was an intact open reading frame encoding the protein of 706 amino acids. Accordingly, target cleavage by all active Ago proteins is mediated by the conserved tetrad of the DEDX motif (where $\mathrm{X}$ can be D, H, N or K) (Kaya et al. 2016; Swarts et al. 2014b, 2015a; Yuan et al. 2005). Multiple sequence alignment was carried out, especially focusing on the regions containing the DEDX motif (Fig. 1b). Most importantly, we found that the DEDD tetrad occurred in MfAgo, suggesting that $M f$ Ago may have endonuclease catalytic activity that needs characterization in vitro.

\section{Expression and purification of the recombinant $M f A g o$}

The gene-encoding MfAgo was codon-optimized and built into the plasmid pET-28a(+), which has an $\mathrm{N}$-terminal His-tag and was then transformed into $E$. coli BL21(DE3). Expression in the recombinant E. coli BL21(DE3) was induced by IPTG at $20^{\circ} \mathrm{C}$, and the resulting protein was then purified using an Ni-NTA affinity column. SDS-PAGE analysis showed that the purified protein size was consistent with the estimated molecular weight of recombinant protein $(85.8 \mathrm{kDa})$, which indicated that the recombinant MfAgo was successfully expressed in E. coli BL21(DE3) in a soluble form (Fig. 2a). Then, the size-exclusion chromatography elution showed a single peak, indicating that the purified recombinant $M f$ Ago was a monomer (Fig. 2b). Here, the recombinant MfAgo, purified by Ni-NTA and size exclusion, could be used for subsequent cleavage activity assays in vitro.

\section{Enzymatic characterization of the recombinant MfAgo in vitro \\ Endonuclease activity of MfAgo}

To investigate the enzyme properties of the recombinant MfAgo, we investigated nucleic acid cleavage via a variety of nucleic acid guides in vitro. First, we designed 16-nucleotide (nt) ssDNA or ssRNA guides with a $5^{\prime}$ phosphate or $5^{\prime}$ hydroxyl group to cleave complementary FAM-labeled ssDNA or ssRNA targets (Fig. 3a). Strikingly, the results showed that MfAgo cleaved complementary ssDNA targets using $5^{\prime}$-P ssDNA, 5'-P ssRNA, or $5^{\prime}-\mathrm{OH}$ ssDNA guides (Fig. 3b). Different kinds of guide preferences have not been observed in other characterized Agos from eukaryotes or prokaryotes. 
a

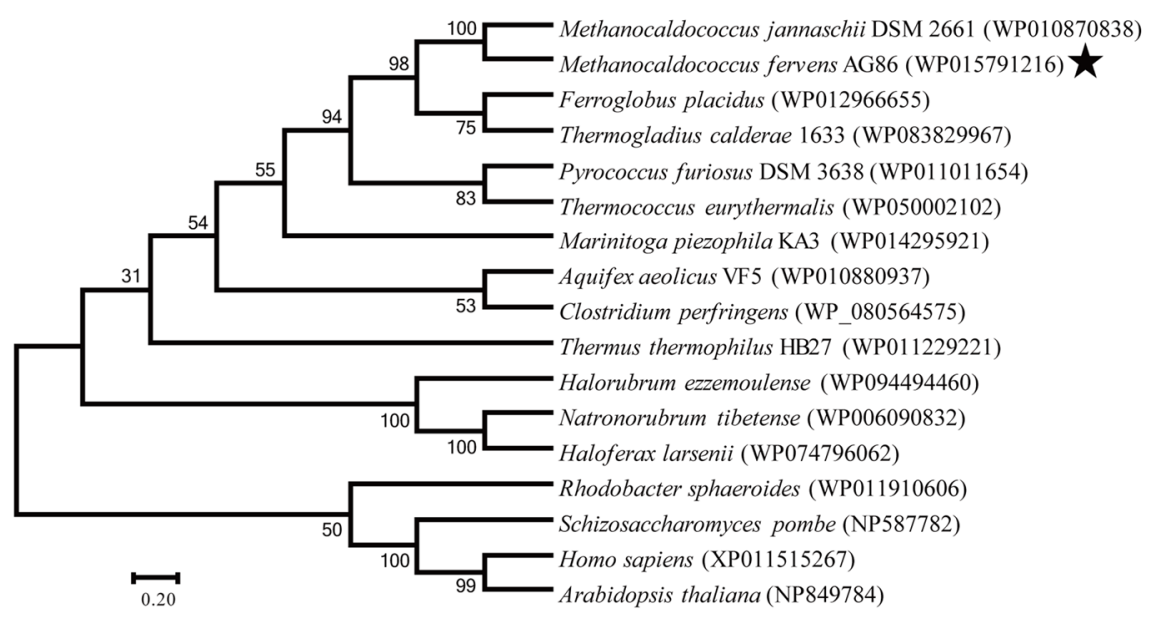

b

\begin{tabular}{|c|c|c|c|c|c|}
\hline & & $\mathrm{D}$ & & $\mathrm{D}_{565}$ & $675 \quad x$ \\
\hline & & & & $\dot{E} N K N I L F I$ & I $\dot{\mathrm{A} P I H Y}$ \\
\hline & & IMGLDTGLGIF I & TPAP . GERLHLP & ENKN I LF LRDGF & I AP I HYADKFVKA \\
\hline & & I IGIDVAPMKR I & IGEQRGESVDMN & I DNKKILLLRDGR & I APVHYAHKFANA \\
\hline & & FVGIDISRITR I & YPAF . GEKLTEK & I GSK. IVVHRDGR I & I ATVHYSDKITKL \\
\hline & & LAVGFDAGGR I & PEAQAGERIPQE & | LPSRVLLLRDGR | & I APLHLADRLVKE \\
\hline
\end{tabular}

Fig. 1 Phylogenetic tree and sequence analysis. a Neighbor-joining phylogenetic tree analysis of MfAgo based on amino acid sequences. The numbers at the nodes indicate the bootstrap values for neighbor-joining analysis of 1000 resampled data sets. The scale bar represents the evolutionary distance between species. Numbers in parentheses represent the sequence accession numbers in the NCBI database. b Multiple sequence alignments of MfAgo with other known pAgos. MjAgo: Ago from Methanocaldococcus jannaschii. PfAgo: Ago from Pyrococcus furiosus. AaAgo: Ago from Aquifex aeolicus. TtAgo: Ago from Thermus thermophilus. Only regions containing the DEDX catalytic residues (indicated in red) are shown. The alignment was carried out using ClustalW, shaded manually and using ESPript 3.0 (Robert and Gouet 2014)

a

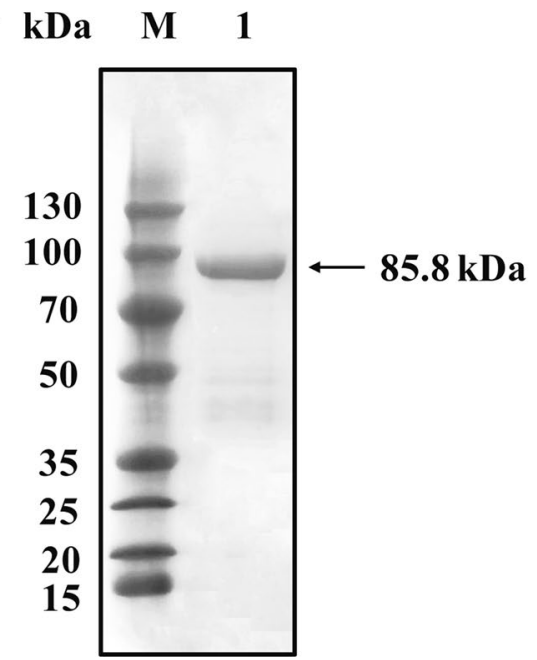

b

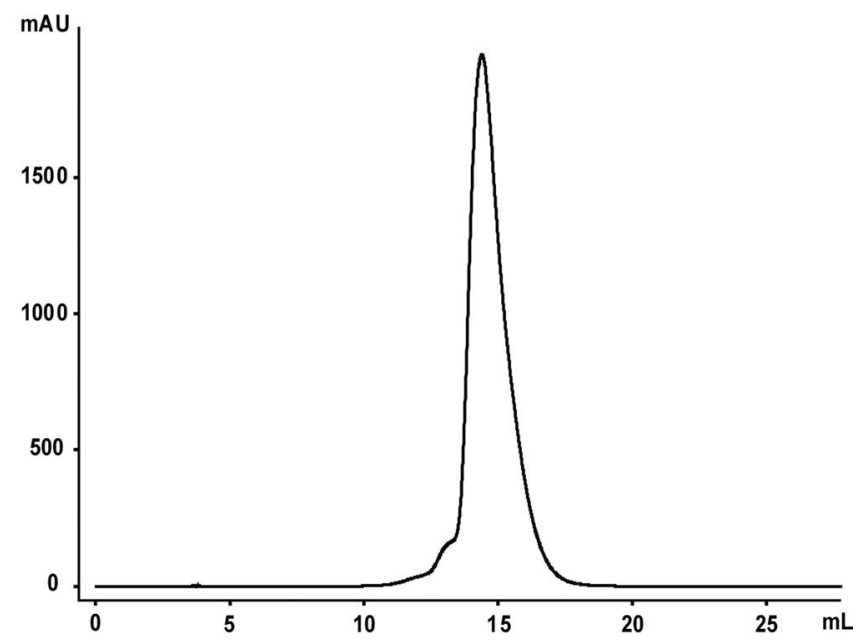

Fig. 2 Purification of the MfAgo protein. a SDS-PAGE analysis of Ni-NTA-purified MfAgo. M: protein marker; lane 1: purified MfAgo. b Chromatograms of size-exclusion chromatography for MfAgo. The measured UV absorbance (mAU) at $280 \mathrm{~nm}$ is shown against the elution volume $(\mathrm{mL})$ 

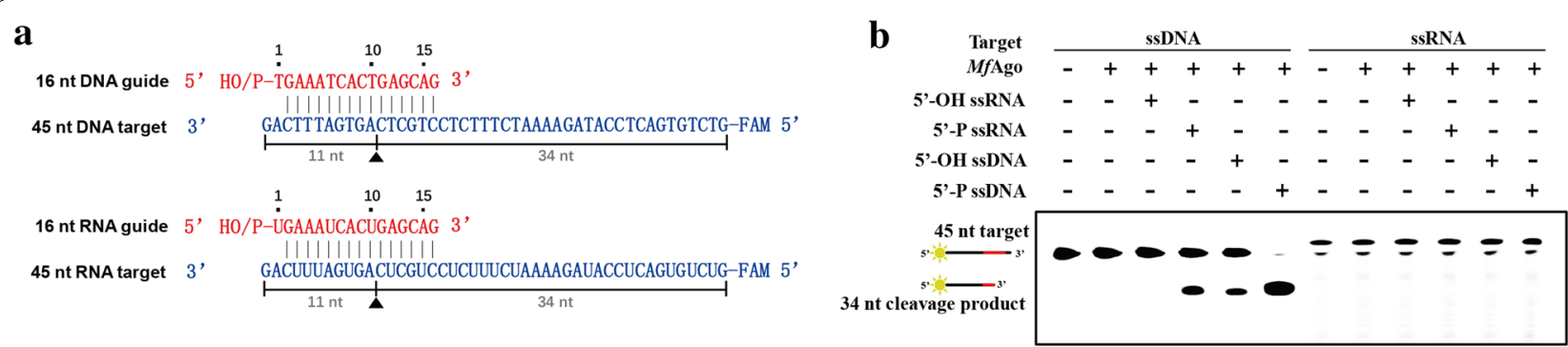

Fig. 3 Endonuclease activity assays of MfAgo in vitro. a Synthetic DNA or RNA guides (red) and targets (blue). Predicted cleavage positions are indicated with a black triangle, black lines indicate the predicted 11- and 34-nt cleavage products. $\mathbf{b}$ Cleavage activity assay of MfAgo with FAM-labeled DNA or RNA targets

Meanwhile, the results also indicated that, like other characterized Agos, MfAgo cleaved the complementary target DNA strand at the complementary site between nucleotides 10 and 11 of the guide strand, but there were some differences in cleavage efficiency mediated by three different kinds of guides.

\section{MfAgo catalytic activity affected by temperature}

The cleavage activity of active pAgos is strongly temperature dependent (Swarts et al. 2015a; Wang et al. 2009); thus, we tested the influence of temperature on recombinant $M f A g o$ ssDNA cleavage activity mediated by three different kinds of guides (Fig. 4). The optimum temperatures of MfAgo were significantly different when directed by varied guides: the $5^{\prime}-\mathrm{P}$ ssDNA guide-mediated MfAgo was most active in the range from 85 to $98.7{ }^{\circ} \mathrm{C}$, achieving nearly $100 \%$ cleavage for the ssDNA target; the activity of $5^{\prime}-\mathrm{OH}$ ssDNA guide-mediated $M f A g o$ was enhanced with increasing temperature from 54.8 to $90{ }^{\circ} \mathrm{C}$ and then decreased rapidly with higher temperature (Fig. 4a), which might be caused by the weaker interaction between $5^{\prime}-\mathrm{OH}$ ssDNA guide and $M f$ Ago than interaction between $5^{\prime}-\mathrm{P}$ ssDNA guide and MfAgo.

For the DNA cleavage of $5^{\prime}$-P ssRNA guide-mediated MfAgo, we observed that the activity increased at the temperature range from 54.8 to $85{ }^{\circ} \mathrm{C}$, then decreased rapidly at higher temperature and almost lost at $95{ }^{\circ} \mathrm{C}$ (Fig. 4b). Distinct to highly stable ssDNA guides, the $5^{\prime}$-P ssRNA guide could be degraded partially under high temperature (Additional file 1: Fig. S1). Therefore, we assumed that the reduction of $M f$ Ago cleavage activity over $85^{\circ} \mathrm{C}$ might be a result of the $5^{\prime}$-P ssRNA degradation (Additional file 1: Fig. S2) together with the weakening interaction between guide and MfAgo under high temperatures.

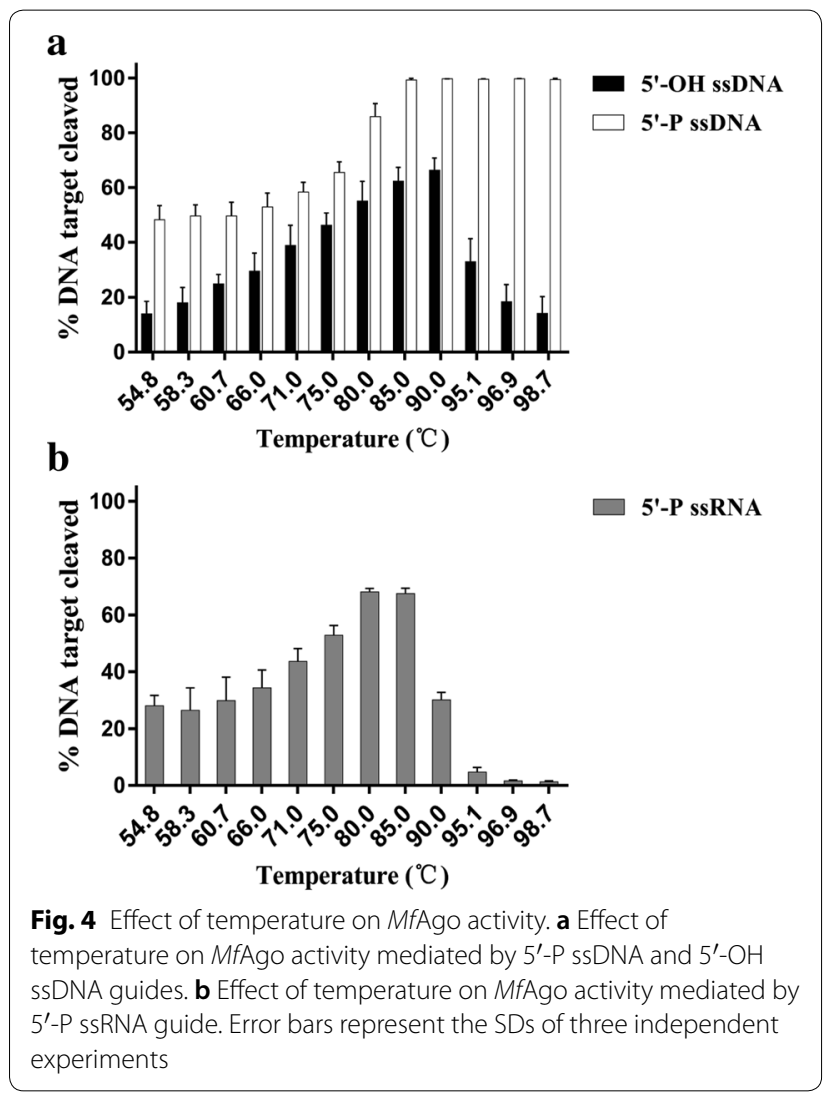

\section{MfAgo catalytic activity affected by divalent cations}

Ago proteins are divalent cation-dependent endonucleases (Nowotny et al. 2005; Song et al. 2004), and the presence of divalent cations is essential for pAgos to specifically bind the $5^{\prime}$ end of the guide strand (Parker 2010; Sheng et al. 2014; Wang et al. 2009). To investigate which divalent cations $M f$ Ago can be utilized for cleavage, different divalent cations at a final concentration of $0.5 \mathrm{mM}$ were added to the reaction system. MfAgo was active 
with $\mathrm{Mn}^{2+}, \mathrm{Co}^{2+}$, and $\mathrm{Mg}^{2+}$, with $\mathrm{Mn}^{2+}$ giving higher activity than $\mathrm{Co}^{2+}$ and $\mathrm{Mg}^{2+}$ (Fig. 5a).

To further determine the optimal concentration of $\mathrm{Mn}^{2+}$ required for $M f$ Ago activity, a series of $\mathrm{Mn}^{2+}$ concentrations was used for MfAgo activity analysis (Fig. 5b). Increased concentrations of $\mathrm{Mn}^{2+}$ improved MfAgo activity mediated by three different guides. Interestingly, $M f$ Ago guide-mediated cleavage of ssDNA targets has different $\mathrm{Mn}^{2+}$ concentration requirements depending on the guide. MfAgo that binds a $5^{\prime}$-P ssDNA guide cleaved almost $100 \%$ of ssDNA targets when the concentration of $\mathrm{Mn}^{2+}$ was greater than $10 \mu \mathrm{M}$. However, MfAgo that binds 5'-OH ssDNA or $5^{\prime}-\mathrm{P}$ ssRNA guides cannot cleave the target nucleic acid completely, even at $\mathrm{Mn}^{2+}$ concentrations as high as $2000 \mu \mathrm{M}$.

\section{MfAgo catalytic activity strongly related to $\mathrm{NaCl}$ concentration}

As $\mathrm{NaCl}$ plays an important role in maintaining the catalytic activity and stability of pAgos (Swarts et al. 2014a, 2015a), we investigated the effects of the $\mathrm{NaCl}$ concentration on MfAgo activity (Fig. 6). MfAgo activity mediated by the $5^{\prime}-\mathrm{P}$ ssDNA guide was highest in the $\mathrm{NaCl}$ concentration range from 100 to $1000 \mathrm{mM}$. $M f$ Ago activity mediated by $5^{\prime}-\mathrm{P}$ ssRNA and $5^{\prime}-\mathrm{OH}$ ssDNA guides achieves maximum cleavage at $\mathrm{NaCl}$ concentrations of $100 \mathrm{mM}$ and $500 \mathrm{mM}$, respectively. Furthermore, higher $\mathrm{NaCl}$ concentrations could inhibit the cleavage activity of $M f$ Ago.

\section{Kinetic performance of MfAgo}

To further investigate the catalytic properties of $M f$ Ago mediated by three different guides, we performed a cleavage kinetics assay at $85{ }^{\circ} \mathrm{C}$ with $250 \mathrm{mM} \mathrm{NaCl}$ and
$2 \mathrm{mM} \mathrm{Mn}^{2+}$ (Fig. 7). The results indicated that MfAgo exhibited the highest cleavage efficiency for the DNA target when utilizing the $5^{\prime}$-P ssDNA guide. In contrast, $M f$ Ago activity mediated by the $5^{\prime}-\mathrm{OH}$ ssDNA guide was less efficient, and the cleavage efficiency of $M f A g o$ using the $5^{\prime}$-P ssRNA guide was the lowest. Therefore, MfAgo prefers to use $5^{\prime}$-P ssDNA nucleic acid as a guide strand.

\section{Homology modeling and structural analysis of key interactions between guides and the MID domain of MfAgo}

Homology modeling has been extensively used to generate reliable three-dimensional protein structure models. With the complex structure of MjAgo with its $5^{\prime}-\mathrm{P}$ ssDNA guide (PDB ID: 5G5T, identity $68 \%$ ) as a template, we used SWISS-MODEL to construct the structure of MfAgo (data not shown). Similarly, the architecture of

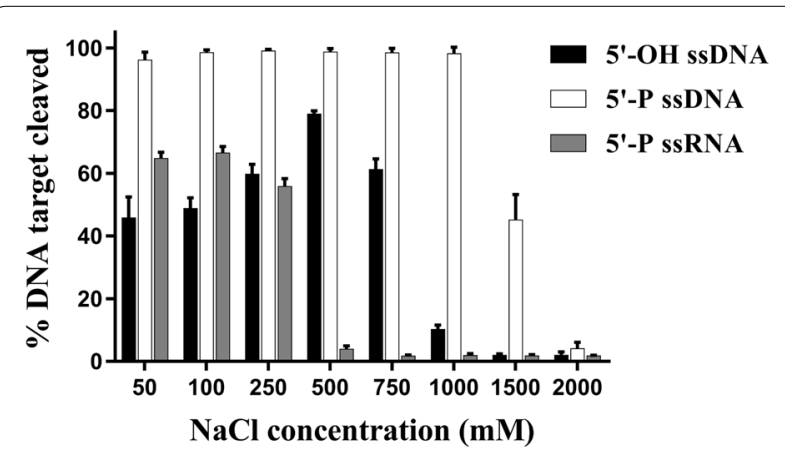

Fig. 6 Effect of $\mathrm{NaCl}$ on the enzyme activity of MfAgo. Error bars represent the SDs of three independent experiments

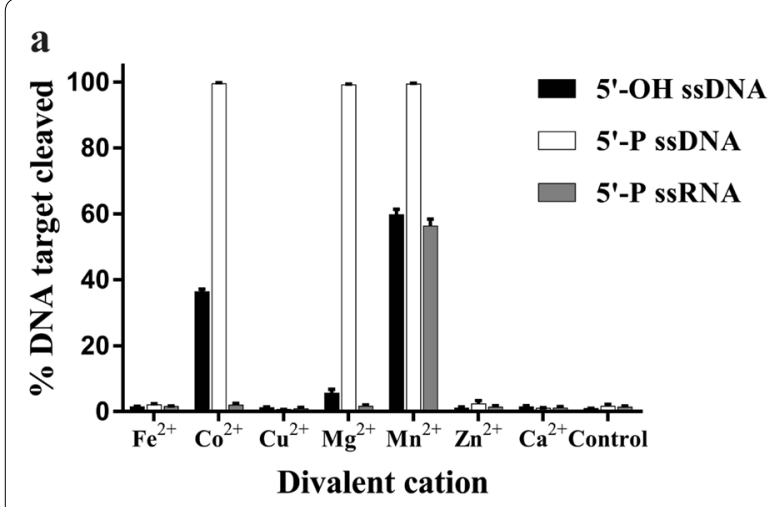

b

Fig. 5 Effects of different divalent cations and $\mathrm{Mn}^{2+}$ concentrations on MfAgo activity. a Effect of different divalent cations on enzyme activity. $\mathbf{b}$ Effect of $\mathrm{Mn}^{2+}$ concentration on enzyme activity. Error bars represent the SDs of three independent experiments 


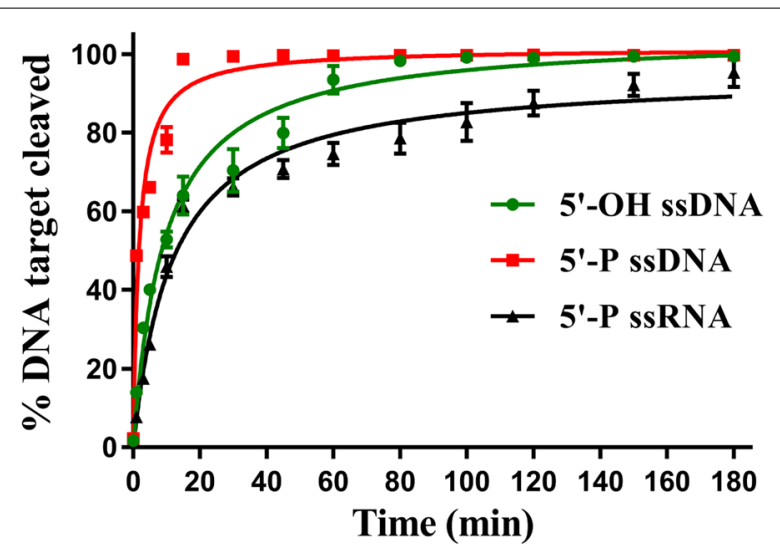

Fig. 7 Kinetic performance of MfAgo mediated by three different kinds of guides. Assays were performed in three independent experiments and plotted using nonlinear regression. SDs are represented by error bars

MfAgo displays a typical pAgo protein structure, which has four domains and two linker regions, forming a bilobal scaffold composed of a PIWI (P element-induced wimpy testis) domain, a MID (middle) domain, a PAZ (Piwi-Argonaute-Zwille) domain and an N-terminal domain, and connecting linkers L1 and L2 (Parker et al. 2005; Rashid et al. 2007; Schirle and MacRae 2012; Song et al. 2004).
To better understand the specific guide recognition mechanism of MfAgo, the guides $5^{\prime}-\mathrm{OH}$ ssDNA, 5'-P ssDNA, and $5^{\prime}$-P ssRNA were individually docked into the MfAgo structure. Ago proteins use a pocket in the MID domain for binding the $5^{\prime}$ end of guides (Kaya et al. 2016; Sheng et al. 2014); thus, potential interactions between the MID domain and different nucleic acid guides were examined (Fig. $8 \mathrm{a}-\mathrm{c}$ ). In previous studies, TtAgo contains a binding pocket with multiple charged residues for recognizing and binding the $5^{\prime}$ phosphate group of the guide (Fig. 8d), while the MID-binding pocket of $M p$ Ago contains a hydrophobic pocket devoid of charged residues around the 5'-hydroxy group (Fig. 8e). In contrast, it seems that the MID-binding pocket of MfAgo possesses both hydrophobic residues and hydrophilic residues and that the hydrophobic residues Leu ${ }^{453}$ and $\mathrm{Tyr}^{434}$ might interact with the $5^{\prime}$-hydroxyl group of guide DNA (Fig. 8a). Furthermore, the lack of a key $\alpha$-helix that exists in MpAgo at the C-terminus of the PIWI domain would result a less-compressed MID-binding pocket in MfAgo, therefore providing sufficient space to bind the $5^{\prime}$ phosphate group.

Inspection of the structure of MfAgo complexed with a $5^{\prime}-\mathrm{OH}$ ssDNA guide indicated that only residue $\mathrm{Asp}^{433}$ might form a single hydrogen bond with $5^{\prime}-\mathrm{OH}$ in ssDNA (Table 3). However, when the $5^{\prime}$-phosphate guide

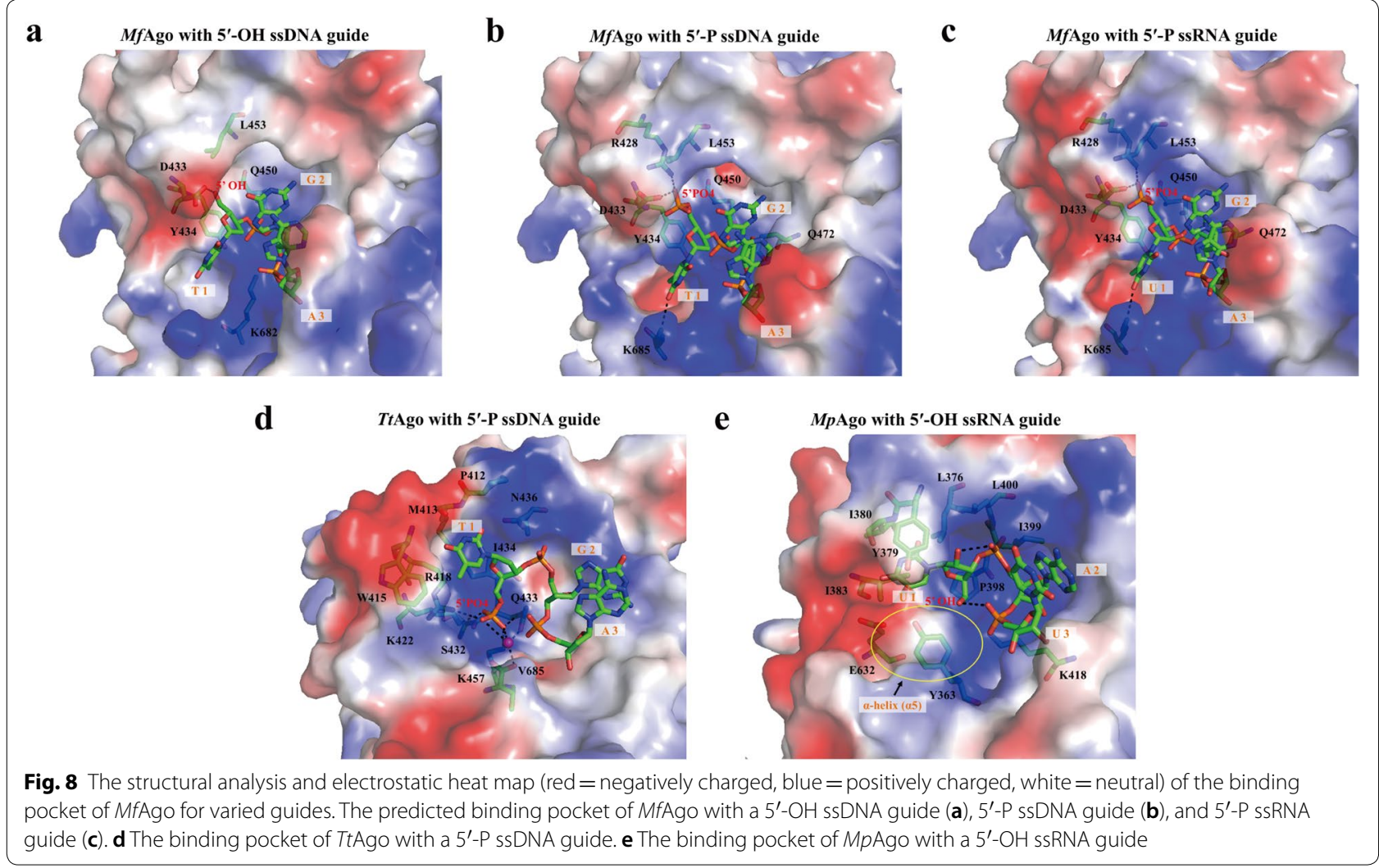


Table 3 Residues of MfAgo to interact with the $5^{\prime}$ end of the guide

\begin{tabular}{|c|c|c|c|c|}
\hline \multicolumn{2}{|l|}{ Guide } & \multicolumn{2}{|l|}{ MfAgo } & \multirow[t]{2}{*}{ Distance $(\AA ̊)$} \\
\hline Type & Atom & Residue & Atom & \\
\hline $5^{\prime}-\mathrm{OH}$ ssDNA & O5' & $\mathrm{Asp}^{433}$ & $\mathrm{O}^{\delta 1}$ & 2.8 \\
\hline \multirow[t]{3}{*}{ 5'-P ssDNA } & $\mathrm{OP} 2$ & $\operatorname{Arg}^{428}$ & $N^{n 1}$ & 2.9 \\
\hline & OP2 & $A_{s p} 433$ & $\mathrm{O}^{\delta 1}$ & 2.5 \\
\hline & $\mathrm{O} 4$ & Lys $^{685}$ & $N^{\zeta}$ & 3.3 \\
\hline \multirow[t]{3}{*}{$5^{\prime}-\mathrm{P}$ ssRNA } & OP2 & $\operatorname{Arg}^{428}$ & $N^{n 1}$ & 2.9 \\
\hline & OP2 & $\mathrm{Asp}^{433}$ & $\mathrm{O}^{\delta 1}$ & 2.5 \\
\hline & $\mathrm{O} 4$ & Lys $^{685}$ & $N^{\zeta}$ & 3.3 \\
\hline
\end{tabular}

was docked into MfAgo, the residues $\mathrm{Arg}^{428}$ and $\mathrm{Asp}^{433}$ in the MID domain created multiple hydrogen-bonding interactions with the phosphate group of the guide, and another key residue, Lys ${ }^{685}$, is involved in hydrogenbonding interactions with the $5^{\prime}$-terminal base of guide DNA/RNA, implying a stronger $M$ fAgo-binding affinity for $5^{\prime}-\mathrm{P}$ guides than for $5^{\prime}-\mathrm{OH}$ guides. These results might be the reason that the catalytic activity and optimal temperature of $M f$ Ago are higher with a 5'-P ssDNA guide than with a $5^{\prime}-\mathrm{OH}$ ssDNA guide.

\section{Conclusion}

$M f$ Ago was cloned and overexpressed in E. coli BL21(DE3). The biochemical characterization revealed that $M f A g o$ catalyzes ssDNA target cleavage directed by either 5'-P ssDNA, 5'-OH ssDNA, or 5'-P ssRNA guides, which is distinguished from the behavior of all other characterized eukaryotic or prokaryotic Agos. MfAgo functions as an endonuclease for DNA target cleavage that requires divalent cations such as $\mathrm{Mn}^{2+}, \mathrm{Mg}^{2+}$, or $\mathrm{Co}^{2+}$ for its activity, with $\mathrm{Mn}^{2+}$ being the cation resulting in the highest activity. The maximum cleavage activity was achieved at $90^{\circ} \mathrm{C}$ for $5^{\prime}-\mathrm{OH}$ ssDNA and $80-85^{\circ} \mathrm{C}$ for $5^{\prime}$-P ssRNA guide-directed $M$ fAgo, whereas $85-98.7^{\circ} \mathrm{C}$ was optimal for the $5^{\prime}$-P DNA guide-directed MfAgo. Meanwhile, $M f A g o$ is quite active in reactions with an $\mathrm{NaCl}$ concentration less than $500 \mathrm{mM}$, whereas higher $\mathrm{NaCl}$ concentrations inhibit the activity of MfAgo. Furthermore, our structural modeling studies revealed that $M f$ Ago has a distinct pocket in the MID domain for binding the $5^{\prime}$-end group of guides and that the different catalytic activities of $M f$ Ago with diverse guides might drive from varied hydrogen-binding interactions between the $5^{\prime}$-end group of guides and several key residues in this binding pocket. Characterization of $M f$ Ago expands the understanding of the pAgo family and will inspire the development of these new Ago proteins' potential applications in genetic manipulation.

\section{Additional file}

Additional file 1. Additional figures.

\begin{abstract}
Abbreviations
Ago: argonaute protein; pAgo: prokaryotic argonaute protein; eAgo: eukaryotic argonaute protein; MfAgo: Methanocaldococcus fervens argonaute protein; PfAgo: Pyrococcus furiosus argonaute protein; AaAgo: Aquifex aeolicus argonaute protein; MjAgo: Methanocaldococcus jannaschii argonaute protein; TtAgo: Thermus thermophilus argonaute protein; MpAgo: Marinitoga piezophila argonaute protein; TpAgo: Thermotoga profunda argonaute protein; RsAgo: Rhodobacter sphaeroides argonaute protein; ssDNA: single-stranded DNA; 5'-P ssDNA: 5'-phosphorylated single-stranded DNA; 5'-OH ssDNA: 5'-hydroxylated single-stranded DNA; 5'-P ssRNA: 5'-phosphorylated single-stranded RNA; ARE: artificial restriction enzyme.
\end{abstract}

\section{Acknowledgements}

Not applicable.

\section{Authors' contributions}

YF conceived the study and modified the manuscript. YSC designed and performed the experiments, analyzed the data, and wrote the manuscript. QL was involved in project planning and manuscript revisions. FH constructed the E. coli BL21(DE3) expression vector and wrote a part of the manuscript. DS carried out the homology modeling and molecular docking. All authors read and approved the final manuscript.

\section{Funding}

This work was funded by the National Natural Science Foundation of China (31770078) and Ministry of Science and Technology (2017YFE0103300).

Availability of data and materials

All data generated or analyzed during this study are included in this published article.

Ethics approval and consent to participate

Not applicable.

\section{Consent for publication}

Not applicable.

\section{Competing interests}

The authors declare that they have no competing interests.

Received: 14 March 2019 Accepted: 16 May 2019

Published online: 05 June 2019

\section{References}

Bartel DP (2009) MicroRNAs: target recognition and regulatory functions. Cell 136(2):215-233. https://doi.org/10.1016/j.cell.2009.01.002

Doxzen KW, Doudna JA (2017) DNA recognition by an RNA-guided bacterial argonaute. PLoS ONE 12(5):e0177097. https://doi.org/10.1371/journ al.pone.0177097

Enghiad B, Zhao H (2017) Programmable DNA-guided artificial restriction enzymes. ACS Synth Biol 6(5):752-757. https://doi.org/10.1021/acssy nbio.6b00324

Kaya E, Doxzen KW, Knoll KR, Wilson RC, Strutt SC, Kranzusch PJ, Doudna JA (2016) A bacterial argonaute with noncanonical guide RNA specificity. Proc Natl Acad Sci USA 113(15):4057-4062. https://doi.org/10.1073/ pnas.1524385113

Ketting RF (2011) The many faces of RNAi. Dev Cell 20(2):148-161. https://doi. org/10.1016/j.devcel.2011.01.012

Koonin EV (2017) Evolution of RNA- and DNA-guided antivirus defense systems in prokaryotes and eukaryotes: common ancestry vs convergence. Biol Direct 12(1):5. https://doi.org/10.1186/s13062-017-0177-2 
Kumar S, Stecher G, Tamura K (2016) MEGA7: molecular evolutionary genetics analysis version 7.0 for bigger datasets. Mol Biol Evol 33(7):1870-1874. https://doi.org/10.1093/molbev/msw054

Makarova KS, Wolf YI, van der Oost J, Koonin EV (2009) Prokaryotic homologs of argonaute proteins are predicted to function as key components of a novel system of defense against mobile genetic elements. Biol Direct 4(1):29. https://doi.org/10.1186/1745-6150-4-29

Meister G (2013) Argonaute proteins: functional insights and emerging roles. Nat Rev Genet 14(7):447-459. https://doi.org/10.1038/nrg3462

Miyoshi T, Ito K, Murakami R, Uchiumi T (2016) Structural basis for the recognition of guide RNA and target DNA heteroduplex by argonaute. Nat Commun 7:11846. https://doi.org/10.1038/ncomms11846

Nowotny M, Gaidamakov SA, Crouch RJ, Yang W (2005) Crystal structures of RNase $\mathrm{H}$ bound to an RNA/DNA hybrid: substrate specificity and metaldependent catalysis. Cell 121(7):1005-1016. https://doi.org/10.1016/j. cell.2005.04.024

Olovnikov I, Chan K, Sachidanandam R, Newman DK, Aravin AA (2013) Bacterial argonaute samples the transcriptome to identify foreign DNA. Mol Cell 51(5):594-605. https://doi.org/10.1016/j.molcel.2013.08.014

Parker JS (2010) How to slice: snapshots of argonaute in action. Silence 1(1):3. https://doi.org/10.1186/1758-907X-1-3

Parker JS, Roe SM, Barford D (2005) Structural insights into mRNA recognition from a PIWI domain-siRNA guide complex. Nature 434(7033):663-666. https://doi.org/10.1038/nature03462

Rashid UJ, Paterok D, Koglin A, Gohlke H, Piehler J, Chen JC (2007) Structure of Aquifex aeolicus argonaute highlights conformational flexibility of the PAZ domain as a potential regulator of RNA-induced silencing complex function. J Biol Chem 282(18):13824-13832. https://doi.org/10.1074/jbc. M608619200

Repasky MP, Shelley M, Friesner RA (2007) Flexible ligand docking with glide. Curr Protoc Bioinform. https://doi.org/10.1002/0471250953.bi0812s18

Rivas FV, Tolia NH, Song JJ, Aragon JP, Liu J, Hannon GJ, Joshua-Tor L (2005) Purified argonaute2 and an siRNA form recombinant human RISC. Nat Struct Mol Biol 12(4):340-349. https://doi.org/10.1038/nsmb918

Robert X, Gouet P (2014) Deciphering key features in protein structures with the new ENDscript server. Nucleic Acids Res 42:W320-W324. https://doi org/10.1093/nar/gku316

Ryazansky S, Kulbachinskiy A, Aravin AA (2018) The expanded universe of prokaryotic argonaute proteins. Mbio. https://doi.org/10.1128/ mBio.01935-18

Schirle NT, MacRae IJ (2012) The crystal structure of human argonaute2. Science 336(6084):1037-1040. https://doi.org/10.1126/science.1221551

Sheng G, Zhao H, Wang J, Rao Y, Tian W, Swarts DC, van der Oost J, Patel DJ, Wang Y (2014) Structure-based cleavage mechanism of Thermus thermophilus argonaute DNA guide strand-mediated DNA target cleavage. Proc Natl Acad Sci USA 111(2):652-657. https://doi.org/10.1073/pnas.13210 32111

Siomi MC, Sato K, Pezic D, Aravin AA (2011) PIWl-interacting small RNAs: the vanguard of genome defence. Nat Rev Mol Cell Biol 12(4):246-258. https ://doi.org/10.1038/nrm3089

Song JJ, Smith SK, Hannon GJ, Joshua-Tor L (2004) Crystal structure of argonaute and its implications for RISC slicer activity. Science 305(5689):14341437. https://doi.org/10.1126/science.1102514

Swarts DC, Jore MM, Westra ER, Zhu Y, Janssen JH, Snijders AP, Wang Y, Patel DJ, Berenguer J, Brouns SJJ, van der Oost J (2014a) DNA-guided DNA interference by a prokaryotic argonaute. Nature 507(7491):258-261. https://doi. org/10.1038/nature12971

Swarts DC, Makarova K, Wang Y, Nakanishi K, Ketting RF, Koonin EV, Patel DJ, van der Oost J (2014b) The evolutionary journey of argonaute proteins. Nat Struct Mol Biol 21(9):743-753. https://doi.org/10.1038/nsmb.2879

Swarts DC, Hegge JW, Hinojo I, Shiimori M, Ellis MA, Dumrongkulraksa J, Terns RM, Terns MP, van der Oost J (2015a) Argonaute of the archae on Pyrococcus furiosus is a DNA-guided nuclease that targets cognate DNA. Nucleic Acids Res 43(10):5120-5129. https://doi.org/10.1093/nar/gkv415

Swarts DC, Koehorst JJ, Westra ER, Schaap PJ, van der Oost J (2015b) Effects of argonaute on gene expression in Thermus thermophilus. PLOS ONE 10(4):e0124880. https://doi.org/10.1371/journal.pone.0124880

Swarts DC, Szczepaniak M, Sheng G, Chandradoss SD, Zhu Y, Timmers EM, Zhang Y, Zhao H, Lou J, Wang Y, Joo C, van der Oost J (2017) Autonomous generation and loading of DNA guides by bacterial argonaute. Mol Cell 65(6):985-998. https://doi.org/10.1016/j.molcel.2017.01.033
Thompson JD, Higgins DG, Gibson TJ (1994) CLUSTAL W: improving the sensitivity of progressive multiple sequence alignment through sequence weighting, position-specific gap penalties and weight matrix choice. Nucleic Acids Res 22(22):4673-4680

Wang Y, Juranek S, Li H, Sheng G, Tuschl T, Patel DJ (2008a) Structure of an argonaute silencing complex with a seed-containing guide DNA and target RNA duplex. Nature 456(7224):921-926. https://doi.org/10.1038/ nature07666

Wang Y, Sheng G, Juranek S, Tuschl T, Patel DJ (2008b) Structure of the guidestrand-containing argonaute silencing complex. Nature 456(7219):209213. https://doi.org/10.1038/nature07315

Wang Y, Juranek S, Li H, Sheng G, Wardle GS, TuschI T, Patel DJ (2009) Nucleation, propagation and cleavage of target RNAs in Ago silencing complexes. Nature 461(7265):754-761. https://doi.org/10.1038/nature08434

Waterhouse A, Bertoni M, Bienert S, Studer G, Tauriello G, Gumienny R, Heer FT, de Beer TAP, Rempfer C, Bordoli L, Lepore R, Schwede T (2018) SWISSMODEL: homology modelling of protein structures and complexes. Nucleic Acids Res 46(W1):W296-W303. https://doi.org/10.1093/nar/ gky427

Willkomm S, Oellig CA, Zander A, Restle T, Keegan R, Grohmann D, Schneider S (2017) Structural and mechanistic insights into an archaeal DNA-guided argonaute protein. Nat Microbiol 2:17035. https://doi.org/10.1038/nmicr obiol.2017.35

Yuan YR, Pei Y, Ma JB, Kuryavyi V, Zhadina M, Meister G, Chen HY, Dauter Z, Tuschl T, Patel DJ (2005) Crystal structure of A. aeolicus argonaute, a site-specific DNA-guided endoribonuclease, provides insights into RISC-mediated mRNA cleavage. Mol Cell 19(3):405-419. https://doi. org/10.1016/j.molcel.2005.07.011

Yuan YR, Pei Y, Chen HY, Tuschl T, Patel DJ (2006) A potential protein-RNA recognition event along the RISC-loading pathway from the structure of $A$. aeolicus argonaute with externally bound siRNA. Structure 14(10):15571565. https://doi.org/10.1016/j.str.2006.08.009

Zander A, Holzmeister P, Klose D, Tinnefeld P, Grohmann D (2014) Singlemolecule FRET supports the two-state model of argonaute action. RNA Biol 11(1):45-56. https://doi.org/10.4161/rna.27446

Zander A, Willkomm S, Ofer S, van Wolferen M, Egert L, Buchmeier S, Stöckl S, Tinnefeld P, Schneider S, Klingl A, Albers SV, Werner F, Grohmann D (2017) Guide-independent DNA cleavage by archaeal argonaute from Methanocaldococcus jannaschii. Nat Microbiol 2:17034. https://doi.org/10.1038/ nmicrobiol.2017.34

\section{Publisher's Note}

Springer Nature remains neutral with regard to jurisdictional claims in published maps and institutional affiliations.

\section{Submit your manuscript to a SpringerOpen ${ }^{\circ}$ journal and benefit from:}

- Convenient online submission

- Rigorous peer review

- Open access: articles freely available online

- High visibility within the field

- Retaining the copyright to your article

Submit your next manuscript at $\gg$ springeropen.com 